\title{
Zatory płatnicze a odroczone płatności
}

Gabriela Golawska-Witkowska*, Ewa Mazurek-Krasodomska**, Anna Rzeczycka***

\section{Wprowadzenie}

W Polsce Ustawa o swobodzie działalności gospodarczej nakłada na przedsiębiorstwa obowiązek obrotu bezgotówkowego, gdy wartość realizowanych transakcji przekracza równowartość w złotych 15000 euro (Ustawa z dnia 2 lipca 2004 roku). Obok tego typu transakcji dokonywane są w tym samym trybie również te o niższej wartości. Mamy więc do czynienia z odroczonymi terminami płatności, związanymi z udzieleniem kredytu kupieckiego innym przedsiębiorstwom.

Odroczone płatności obok pozytywnych skutków, w postaci możliwości zwiększenia obrotów, powodują funkcjonowanie przedsiębiorstw w warunkach ryzyka kredytowego. Jego wyrazem jest tworzenie się zatorów płatniczych, które są spowodowane brakiem lub w najlepszym przypadku tylko częściową zapłatą za dostarczone wyroby, towary czy usługi.

Celem artykułu jest przedstawienie zatorów płatniczych jako skutków odroczonych płatności, sprzyjających tworzeniu się ryzyka kredytowego oraz ujemnych luk płynności. Stwierdzono, że kredyt kupiecki może dla wielu firm stanowić istotną przeszkodę w działalności gospodarczej. Podjęto więc próbę oszacowania przyczyn występowania oraz wskazania potencjalnych i realnych metod ograniczania jego skutków.

* Gabriela Golawska-Witkowska, Politechnika Gdańska, Wydział Zarządzania i Ekonomii, Katedra Analizy Ekonomicznej i Finansów, g.golawska@gmail.com

** Ewa Mazurek-Krasodomska, Politechnika Gdańska, Wydział Zarządzania i Ekonomii, Katedra Analizy Ekonomicznej i Finansów, emazurek@zie.pg.gda.pl

*** Anna Rzeczycka, Politechnika Gdańska, Wydział Zarządzania i Ekonomii, Katedra Analizy Ekonomicznej i Finansów, rzeczycka@interia.pl 
Zastosowaną metodą badawczą jest analiza literatury przedmiotu oraz danych statystycznych. W analizach posłużono się wielkościami globalnymi dotyczącymi całej gospodarki oraz wybranych branż. Nie informują one o sytuacji w poszczególnych przedsiębiorstwach, ale pozwalają na pokazanie ogólnych tendencji w zakresie płynności.

\section{Kredyt kupiecki i przyczyny jego występowania}

Płatności za dostarczone wyroby, towary czy usługi w przypadku udzielenia kredytu kupieckiego są odroczone w czasie. Oznacza to, że środki pieniężne przedsiębiorstw zamrożone są w należnościach z tytułu dostaw i usług. Nabywcy towarów czy usług są zobowiązani do dokonania zapłaty w ustalonym terminie w przyszłości, ale już po otrzymaniu dostawy. Może więc okazać się, że:

- nie posiadają oni wystarczających środków na zapłatę swoich zobowiązań płatniczych,

- prowadzą politykę dokonywania zapłaty dopiero po kolejnym wezwaniu do jej uiszczenia.

Konsekwencją takich sytuacji są opóźnienia w płatnościach lub nawet ich zaprzestanie. W efekcie tworzą się zatory płatnicze, których przyczyny mają zarówno zewnętrzny, jak i wewnętrzny charakter. Mogą dotyczyć czynników w skali makro, takich jak polityka pieniężna i fiskalna oraz koniunktura gospodarcza. Przykładowo prowadzona polityka tzw. trudnego pieniądza skutecznie ogranicza możliwości zewnętrznego finansowania przedsiębiorstw. Podobnie nie bez znaczenia jest sytuacja finansów publicznych. Wysoki deficyt może być sfinansowany poprzez emisję papierów skarbowych, które między innymi są nabywane przez banki. Ponieważ ilość środków pieniężnych będących w ich dyspozycji jest ograniczona, banki przeznaczają mniej środków na kredytowanie przedsiębiorstw. Kredyty są więc trudne do pozyskania lub wręcz niedostępne dla niektórych podmiotów gospodarczych, co pogarsza ich sytuację płynnościową. Czynnikiem w skali makro jest również koniunktura gospodarcza. Dekoniunktura gospodarcza związana jest z pogarszaniem kondycji ekonomiczno-finansowej przedsiębiorstw, w tym ich możliwości płatniczych. Wykorzystując współczynnik korelacji Pearsona, określono zależność między jednym z mierników koniunktury, jakim jest wskaźnik bezrobocia, a zatorami płatniczymi. Wskaźnik bezrobocia zmienia się wraz ze standingiem przedsiębiorstw. Jego pogorszenie związane jest często z ograniczeniem wielkości sprzedaży powodującym zwolnienia pracowników. W skali globalnej pojawia się więc zwiększone bezrobocie. Zatory płatnicze wyznaczono natomiast jako udział opóźnionych 
płatności, przekraczających 60 dni w płatnościach ogółem. Współczynnik Paersona dla badanych w latach 2010-2014 zmiennych osiągnął poziom 0,63¹, potwierdzając korelację między koniunkturą, wyrażoną wskaźnikiem bezrobocia, a zatorami płatniczymi w Polsce.

Wewnętrzne przyczyny problemów płynnościowych przedsiębiorstw dotyczą natomiast braku dopasowania kwot i terminów dokonywanych płatności i otrzymywanych wpływów z tytułu sprzedaży wyrobów, towarów czy świadczonych usług. Wynikają więc z braku lub niedostatecznej polityki samego przedsiębiorstwa w zakresie kształtowania jego kapitału obrotowego netto. Firmy w niedostatecznym stopniu wykorzystują swoją rezerwę płynności oraz źle zarządzają środkami pieniężnymi, należnościami, zapasami i zobowiązaniami z tytułu dostaw i usług. Konieczne staje się więc zarządzanie ryzykiem związanym z odroczonymi płatnościami z uwzględnieniem sytuacji makro, jak również w samym przedsiębiorstwie.

Przedsiębiorstwa, kształtując to ryzyko, nie mają jednak większego wpływu na determinanty zewnętrzne w postaci koniunktury gospodarczej, polityki pieniężnej i fiskalnej. Mogą natomiast, uwzględniając czynniki wewnętrzne, zarządzać nim i kształtować poziom płynności w swojej firmie. W tym celu muszą oddziaływać zarówno na aktywną, jak i pasywną stronę bilansu.

\section{Sytuacja przedsiębiorstw w Polsce w zakresie kształtowania należności z tytułu dostaw i usług}

Ważnym elementem kształtowania płynności przedsiębiorstw jest identyfikacja ich sytuacji w zakresie należności z tytułu dostaw i usług. Według danych GUS należności ogółem stanowią ponad 40\% aktywów obrotowych przedsiębiorstw, natomiast te, które wiążą się z dostawami i usługami, tworzą ponad 80\% wszystkich należności przedsiębiorstw. Są więc istotnym elementem, za pomocą którego może być generowane ryzyko kredytowe tkwiące w odroczonych płatnościach. Należności te zostały przedstawione w tabeli 1. Można zauważyć, że poziom należności wykazuje tendencję wzrostową. Wyjątkiem jest 2012 rok, kiedy ich wartość nieco się obniżyła. Warto zwrócić jeszcze uwagę na zmniejszający się udział należności z tego tytułu w przychodach ze sprzedaży. W 2010 roku wynosił on 12,5\%, natomiast cztery lata później nie osiągnął 12\%.

1 Obliczeń dokonano na podstawie danych rocznych. 
Tabela 1. Należności przedsiębiorstw w Polsce

\begin{tabular}{|c|c|c|c|}
\hline Rok & $\begin{array}{c}\text { Należności ogółem } \\
\text { w mln zt }\end{array}$ & $\begin{array}{c}\text { Należności z tytułu } \\
\text { dostaw i usług } \\
\text { w mln zt }\end{array}$ & $\begin{array}{c}\text { Udziat należności z tytułu dostaw } \\
\text { i usług w przychodach ze sprzedaży } \\
\text { (\%) }\end{array}$ \\
\hline 2010 & 383813 & 320035 & 12,5 \\
\hline 2011 & 430099 & 352419 & 12,2 \\
\hline 2012 & 428574 & 348387 & 11,6 \\
\hline 2013 & 433127 & 357055 & 11,8 \\
\hline 2014 & 448974 & 366762 & 11,9 \\
\hline
\end{tabular}

Źródło: opracowanie własne na podstawie Roczników Statystycznych RP 2010-2015.

W gospodarce ponad połowa należności jest regulowana z opóźnieniem. Jednak udział nieterminowych płatności zależy od branży, w której funkcjonują przedsiębiorstwa. Zostało to przedstawione w tabeli 2.

Tabela 2. Odsetek nieterminowo regulowanych należności (\%)

\begin{tabular}{|l|c|c|c|c|c|c|}
\hline $\begin{array}{c}\text { Branża } \\
\text { Okres }\end{array}$ & Ogółem & $\begin{array}{c}\text { Branża } \\
\text { finansowa }\end{array}$ & $\begin{array}{c}\text { Usługi } \\
\text { masowe }\end{array}$ & Przedsiębiorcy & $\begin{array}{c}\text { Branża } \\
\text { budowlana }\end{array}$ & E-commerce \\
\hline X 2010 & 53 & 56 & 55 & 45 & $\mathrm{Bd}$ & $\mathrm{Bd}$ \\
\hline $\mathrm{X} 2011$ & 56 & 46 & 61 & 59 & $\mathrm{Bd}$ & $\mathrm{Bd}$ \\
\hline $\mathrm{XI} 2012$ & 47 & 26 & 60 & 65 & 57 & 46 \\
\hline $\mathrm{XI} 2013$ & 45 & 25 & 58 & 59 & 69 & 31 \\
\hline VI 2014 & 51 & 23 & 63 & 63 & 78 & 48 \\
\hline IV 2015 & 61 & 38 & 57 & 53 & 79 & 63 \\
\hline
\end{tabular}

Źródło: opracowanie własne na podstawie www.RaportBIG.pl.

Nieterminowe płatności stanowią w całej gospodarce około 50\%, a od roku 2013 obserwuje się ich wzrost. Szczególnie trudna sytuacja występuje w branży budowlanej, gdzie od 2012 roku wzrasta odsetek nieterminowo regulowanych płatności. W opinii przedsiębiorców jest to istotna przeszkoda w funkcjonowaniu każdego z nich (tabela 3).

Tabela 3. Nieterminowo regulowane płatności jako przeszkoda w prowadzeniu działalności gospodarczej (\%)

\begin{tabular}{|c|c|c|c|c|c|c|}
\hline $\begin{array}{c}\text { Branża } \\
\text { Okres }\end{array}$ & Ogółem & $\begin{array}{c}\text { Branża } \\
\text { finansowa }\end{array}$ & $\begin{array}{c}\text { Usługi } \\
\text { masowe }\end{array}$ & Przedsiębiorcy & $\begin{array}{c}\text { Branża } \\
\text { budowlana }\end{array}$ & E-commerce \\
\hline X 2010 & 74 & 75 & 71 & 72 & $\mathrm{Bd}$ & $\mathrm{Bd}$ \\
\hline $\mathrm{X} 2011$ & 77 & 77 & 76 & 77 & $\mathrm{Bd}$ & $\mathrm{Bd}$ \\
\hline $\mathrm{XI} 2012$ & 84 & 71 & 80 & 86 & 96 & 83 \\
\hline $\mathrm{XI} 2013$ & 74 & 72 & 75 & 76 & 84 & 62 \\
\hline VI 2014 & 81 & 65 & 78 & 93 & 93 & 83 \\
\hline IV 2015 & 81 & 88 & 80 & 79 & 88 & 75 \\
\hline
\end{tabular}

Źródło: opracowanie własne na podstawie www.RaportBIG.pl. 
W całej gospodarce nieterminowe płatności stanowią ponad $80 \%$ przyczyn trudności w prowadzeniu działalności gospodarczej. Jest to związane z występowaniem należności przedawnionych, umorzonych lub wręcz nieściągalnych. W przedsiębiorstwie skutkuje to znacznym opóźnieniem w odzyskaniu zamrożonych w należnościach kapitałów lub nawet ich utratą. Pojawiają się problemy z utrzymaniem płynności, których wyrazem są zatory płatnicze. W Polsce sytuacja w zakresie rotacji należności i zobowiązań z tytułu dostaw i usług przedstawia się następująco (tabela 4 ).

Tabela 4. Rotacja należności i zobowiązań z tytułu dostaw i usług w dniach w przedsiębiorstwach w Polsce

\begin{tabular}{|l|c|c|c|c|c|}
\hline \multicolumn{1}{|c|}{ Wyszczególnienie } & $\mathbf{2 0 1 0}$ & $\mathbf{2 0 1 1}$ & $\mathbf{2 0 1 2}$ & $\mathbf{2 0 1 3}$ & $\mathbf{2 0 1 4}$ \\
\hline Rotacja należności w dniach & 55 & 44 & 42 & 53 & 53 \\
\hline $\begin{array}{l}\text { Rotacja zobowiązań z tytułu } \\
\text { dostaw i usług w dniach }\end{array}$ & 46 & 45 & 42 & 42 & 42 \\
\hline $\begin{array}{l}\text { Różnica w dniach (rotacja } \\
\text { należności - rotacja } \\
\text { zobowiązań) }\end{array}$ & 9 & -1 & 0 & 11 & 11 \\
\hline
\end{tabular}

Źródło: opracowanie własne na podstawie Roczników Statystycznych RP 2010-2015.

W przedsiębiorstwach w Polsce krótszy jest okres rotacji zobowiązań niż należności. Oznacza to, że firmy muszą szybciej regulować swoje zobowiązania finansowe, niż otrzymają środki pieniężne za dostarczone wyroby, towary czy usługi. Wyjątek stanowi rok 2011, w którym wcześniej otrzymano środki pieniężne należne, a dopiero potem konieczne było dokonanie płatności z tytułu zobowiązań finansowych. Rotacja należności w zależności od branż przedstawia się następująco (tabela 5).

Tabela 5. Rotacja należności w dniach wg branż

\begin{tabular}{|l|c|c|c|c|c|}
\hline Rok & Przemyst & Budownictwo & $\begin{array}{c}\text { Handel } \\
\text { i naprawy }\end{array}$ & Transport & $\begin{array}{c}\text { Ustugi } \\
\text { finansowe }\end{array}$ \\
\hline 2010 & 56 & 74 & 40 & 55 & 166 \\
\hline 2011 & 45 & 64 & 35 & 44 & 104 \\
\hline 2012 & 42 & 64 & 34 & 43 & 96 \\
\hline 2013 & 52 & 86 & 38 & 57 & 146 \\
\hline 2014 & 53 & 83 & 37 & 58 & 157 \\
\hline
\end{tabular}

Źródło: opracowanie na podstawie Małego Rocznika RP, GUS, Warszawa 2005-2015.

Najdłuższe terminy oczekiwania na upłynnienie należności można zaobserwować w usługach finansowych i budownictwie. Rotacja zobowiązań z tytułu dostaw i usług wg branż została przedstawiona w tabeli 6. 
Tabela 6. Rotacja zobowiązań z tytułu dostaw i usług w dniach

\begin{tabular}{|l|c|c|c|c|c|}
\hline Rok & Przemyst & Budownictwo & $\begin{array}{c}\text { Handel } \\
\text { i naprawy }\end{array}$ & Transport & $\begin{array}{c}\text { Usługi } \\
\text { finansowe }\end{array}$ \\
\hline 2010 & 46 & 67 & 46 & 39 & 17 \\
\hline 2011 & 45 & 70 & 46 & 39 & 22 \\
\hline 2012 & 39 & 69 & 44 & 36 & 16 \\
\hline 2013 & 41 & 74 & 43 & 36 & 18 \\
\hline 2014 & 40 & 70 & 43 & 35 & 20 \\
\hline
\end{tabular}

Źródto: opracowanie na podstawie Rocznika Statystycznego RP, GUS, Warszawa 2005-2015.

Najdłuższe terminy płatności występują w budownictwie. Są one jednak krótsze niż terminy płatności należności. Potwierdza to ogólną tendencję obserwowaną w całej gospodarce.

Analizując przedstawione dane, należy stwierdzić, że sytuacja w zakresie odroczonych płatności naraża przedsiębiorstwa na ryzyko kredytowe, które przyczynia się do tworzenia ryzyka płynności.

\section{Zatory płatnicze w Polsce}

Wyrazem problemów płynnościowych przedsiębiorstw są zatory płatnicze. Występują one w Polsce, ale również są charakterystyczne dla obrotu bezgotówkowego w Unii Europejskiej. Struktura płatności wg terminów i branż została przedstawiona w tabelach 7 i 8.

Tabela 7. Struktura płatności wg terminów w Polsce (\%)

\begin{tabular}{|c|c|c|c|c|c|c|}
\hline Rok & W terminie & $<\mathbf{3 0} \mathbf{d n i}$ & $\mathbf{3 0 - 6 0 ~ d n i}$ & $\mathbf{6 0 - 9 0 ~ d n i}$ & $\mathbf{9 0 - 1 2 0 ~ d n i}$ & $>\mathbf{1 2 0} \mathbf{d n i}$ \\
\hline 2008 & 47,0 & 470,1 & 3,3 & 2,4 & 1,6 & 5,6 \\
\hline 2011 & 34,5 & 49,8 & 2,9 & 2,0 & 2,2 & 8,6 \\
\hline 2012 & 23,7 & 57,8 & 3,6 & 2,4 & 2,4 & 10,1 \\
\hline 2013 & 30,5 & 53,5 & 3,1 & 2,1 & 2,1 & 8,7 \\
\hline 2014 & 44,2 & 42,2 & 2,3 & 1,6 & 1,9 & 7,8 \\
\hline
\end{tabular}

Źródło: Raport Barometr płatności na świecie (2014).

Na początku badanego okresu nastąpił znaczny spadek udziału należności płatnych w terminie. W roku 2008 stanowiły one 47\% należności, a w roku 2012 tylko niecałe $24 \%$. Kolejne lata przyniosły natomiast ponowny wzrost udziału należności płatnych w terminie. Nie przekraczają one jednak $45 \%$ ogółu płatności. Na wy- 
kresie 1 przedstawiono strukturę należności ze względu na termin ich płatności, ale przyjmując nieco uproszczony ich podział. Ze względu na tematykę niniejszego opracowania za okres graniczny przyjęto $60 \mathrm{dni}$.

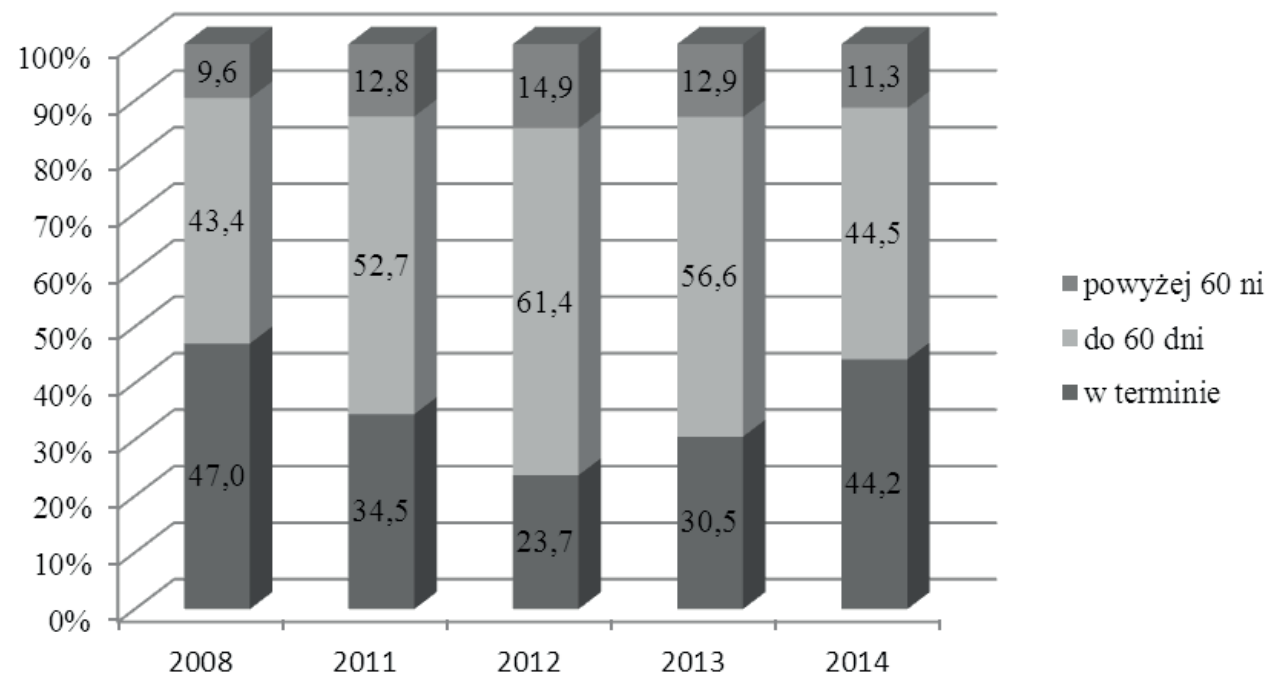

Wykres 1. Struktura płatności należności Źródło: opracowanie własne na postawie tabeli $\mathrm{nr} 7$.

Na początku badanego okresu udział należności o terminie płatności przekraczającym 60 dni wynosił tylko 9,6\%, natomiast kolejne lata przyniosły jego wzrost. Najwyższy poziom przeterminowanych płatności, przekraczający $60 \mathrm{dni}$, odnotowano w 2012 roku. Stanowiły one 14,9\% ogółu płatności. W późniejszym okresie nastąpiła niewielka poprawa w tym zakresie.

Tabela 8. Struktura płatności wg branż (\%) w 2014 roku

\begin{tabular}{|l|c|c|c|c|c|c|}
\hline \multicolumn{1}{|c|}{ Termin } & Budownictwo & Produkcja & Transport & $\begin{array}{c}\text { Sprzedaż } \\
\text { detaliczna }\end{array}$ & $\begin{array}{c}\text { Usługi } \\
\text { finansowe }\end{array}$ & Usługi \\
\hline W terminie & 36,5 & 30,3 & 23,0 & 25,9 & 31,1 & 33,9 \\
\hline$<30 \mathrm{dni}$ & 44,2 & 57,1 & 47,5 & 64,7 & 51,8 & 50,2 \\
\hline $30-60 \mathrm{dni}$ & 2,9 & 3,2 & 4,5 & 2,3 & 2,3 & 3,8 \\
\hline $60-90 \mathrm{dni}$ & 1,9 & 1,7 & 4,3 & 1,6 & 2,7 & 2,3 \\
\hline $90-120 \mathrm{dni}$ & 2,4 & 2,0 & 4,1 & 1,4 & 2,5 & 2,1 \\
\hline$>120 \mathrm{dni}$ & 12,1 & 5,7 & 16,6 & 4,1 & 9,6 & 7,7 \\
\hline
\end{tabular}

Źródto: Raport Barometr płatności na świecie 2015. Bisnote D\&B Polska.

Najwięcej zaległości przekraczających 60 dni występuje w takich branżach jak transport $(25,0 \%)$ oraz budownictwo (16,5\%). Przedstawione analizy pozwalają stwierdzić, że sytuacja przedsiębiorstw w zakresie płynności jest niezadowalająca. 
Również w UE występują opóźnienia w płatnościach. Jednak w większości krajów sytuacja jest lepsza niż w Polsce. Potwierdzają to dane z tabeli 9.

Tabela 9. Struktura płatności w UE w latach 2012-2014

\begin{tabular}{|c|c|c|c|c|c|c|}
\hline $\begin{array}{c}\text { Termin } \\
\text { Rok }\end{array}$ & $\begin{array}{c}\text { Ptatność } \\
\text { w terminie }\end{array}$ & $\mathbf{< 3 0 ~ d n i}$ & $\mathbf{3 0 - 6 0 ~ d n i}$ & $\mathbf{6 0 - 9 0}$ dni & $\mathbf{9 0 - 1 2 0 ~ d n i ~}$ & $>\mathbf{1 2 0}$ dni \\
\hline 2012 & 39,1 & 51,3 & 3,9 & 2,4 & 1,5 & 1,8 \\
\hline 2013 & 38,0 & 51,2 & 4,2 & 2,7 & 1,7 & 2,2 \\
\hline 2014 & 37,6 & 51,6 & 4,4 & 2,6 & 1,6 & 2,2 \\
\hline
\end{tabular}

Źródło: Raport Barometr płatności na świecie 2013. Bisnote D\&B Polska.

W Polsce płatności w terminie charakteryzują się wyższym udziałem w płatnościach ogółem niż w krajach UE ogółem. Jednak w Polsce zatory dotyczące nieterminowych płatności, powyżej 60 dni, kształtują się w 2012 roku na poziomie 14,9\%, w 2013 roku - 12,9\%, w 2014 roku - 11,3\%, podczas gdy w UE odpowiednio $-5,7 \%, 6,6 \%$ oraz $6,4 \%$.

\subsection{Ryzyko kredytowe w obrocie bezgotówkowym}

Przedstawiona w pkt. 2 i 3 sytuacja płynnościowa przedsiębiorstw pozwala na stwierdzenie, że funkcjonują one w warunkach ryzyka kredytowego. Udzielanie kredytu kupieckiego może bowiem wiązać się z opóźnieniem zapłaty lub jej brakiem (Kreczmańska-Gogol 2015, s. 102). Taka sytuacja przekłada się na powstanie problemów płynnościowych, czyli przekształca się w ryzyko płynności (rys. 1).

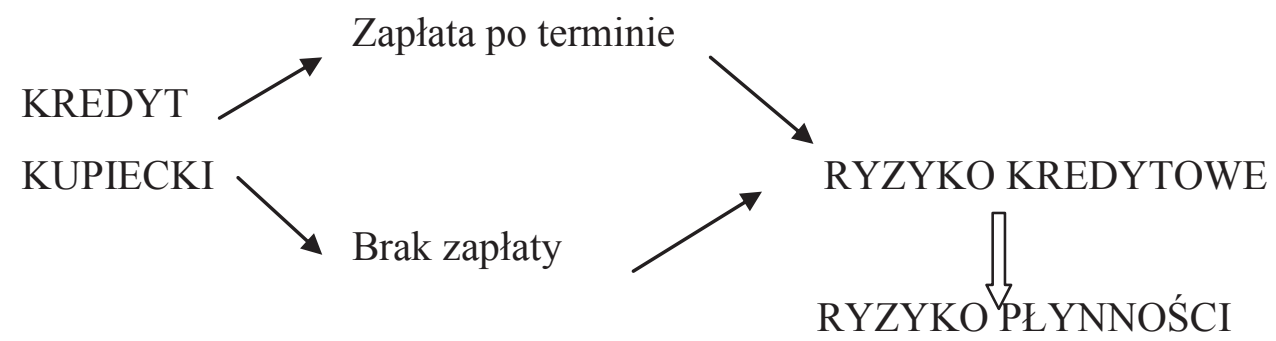

Rysunek 1. Ryzyko związane z kredytem kupieckim

Źródto: opracowanie własne.

Efektem opóźnienia odroczonej w czasie zapłaty lub jej braku jest ryzyko płynności. Jest to sytuacja, w której przedsiębiorstwo nie posiada wystarczających zasobów pieniężnych na pokrycie swoich zobowiązań krótko- i długoterminowych. Wpływy przedsiębiorstwa $z$ działalności operacyjnej, inwestycyjnej i finansowej są więc niższe niż wypływy środków. Mamy więc do czynienia z ujemną luką płynności (rys. 2). 
WPLYWY < WYPLYWY

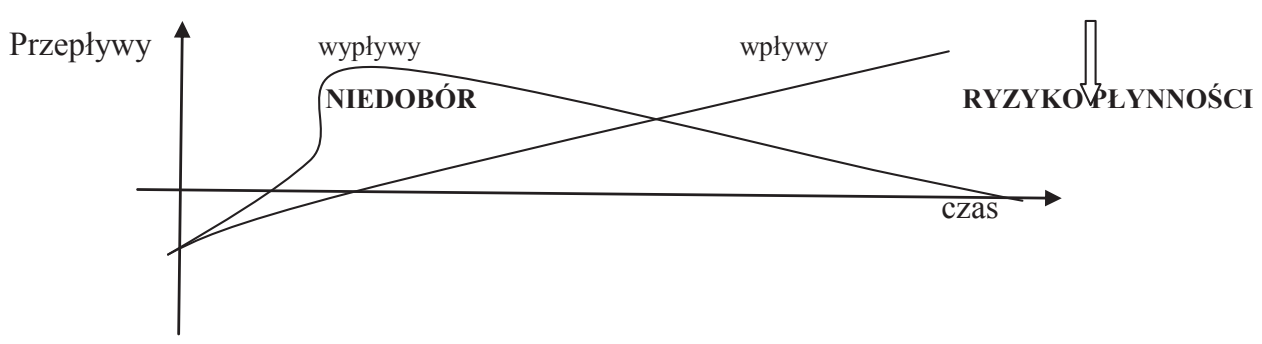

Rysunek 2. Ujemna luka płynności WPŁYWY < WYPŁYWY

Źródto: opracowanie własne.

Szczególnie niebezpieczna dla firmy jest ujemna luka płynności, występująca zarówno w krótkim okresie, jak również dotycząca długiego okresu, oznaczająca trwałe niedobory płynności.

Kredyt kupiecki, który jest ważnym instrumentem finansowania przedsiębiorstw, może więc stanowić źródło ryzyka. $Z$ tego powodu obecnie firmy niekiedy odchodzą od kredytu kupieckiego, żądając przedpłat lub płatności gotówkowej.

Powodem ryzyka wynikającego $\mathrm{z}$ korzystania z kredytu kupieckiego jest asymetria informacji (rys. 3). Strony transakcji nie wiedzą bowiem, czy:

- odbiorca otrzyma towar zgodny z postanowieniami umowy (odpowiednia ilość, jakość i termin dostawy),

- dostawca otrzyma płatność w kwocie i terminie, zgodnie z wystawioną fakturą.

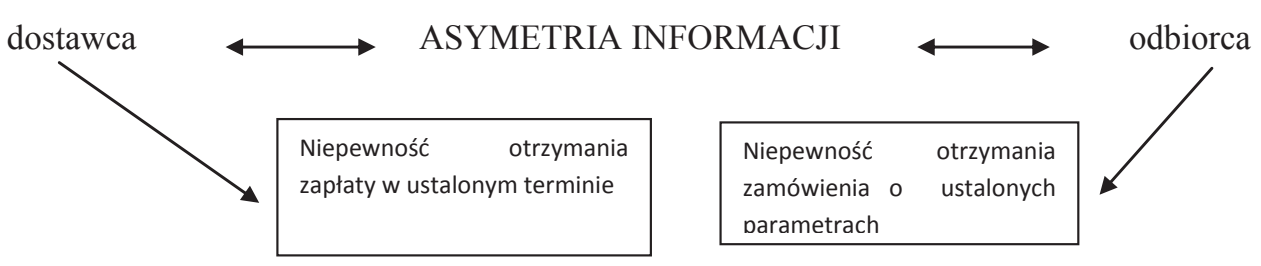

Rysunek 3. Asymetria informacji w transakcjach z odroczonym terminem płatności

Źródło: opracowanie własne.

Negatywne skutki korzystania z kredytu kupieckiego wynikają z niepewności wplecionej $\mathrm{w}$ realizowane transakcje $\mathrm{z}$ odroczonym terminem płatności. Zadaniem przedsiębiorstw jest więc podejmowanie działań mających na celu zmniejszenie lub całkowite wyeliminowanie należności przedawnionych, umorzonych i nieściągalnych. Konieczne staje się zarządzanie należnościami z tytułu dostaw i usług, w szczególności kredytem kupieckim. 


\section{Ograniczanie ryzyka kredytowego w transakcjach z odroczoną płatnością}

Celem zarządzania należnościami z tytułu dostaw i usług jest ustalenie optymalnego rozmiaru kredytu kupieckiego udzielanego odbiorcom. W ten sposób można zabezpieczyć i optymalnie wykorzystać środki zainwestowane w odroczonych płatnościach.

Sposób zarządzania kredytem kupieckim wynika z prowadzonej przez przedsiębiorstwa polityki kredytowej, która pojmowana jest jako zespół decyzji dotyczących okresu kredytowania, standardów kredytowych, udzielanych opustów i procedur ściągania należności. Wykorzystując te instrumenty polityka kredytowa ma za zadanie równoważenie kosztów i korzyści związanych z posiadaniem należności z tytułu dostaw i usług (Jaworski 2010, s. 386). Zgodnie z literaturą przedmiotu wyróżniono trzy etapy zarządzania kredytem kupieckim:

- I etap, dotyczący ograniczania potencjalnego ryzyka w procesie analizy własnej sytuacji płynnościowej, określenia warunków kredytowania, możliwości zmian stosowanej polityki kredytowania oraz ubezpieczenia należności,

- II etap, polegający na wykorzystaniu faktoringu,

- III etap, dotyczący określania metod ściągania należności.

Dokonując oceny funkcjonowania należności, należy określić okres ich rotacji w dniach. Otrzymany wynik należy porównać z:

- planem w zakresie rotacji należności,

- wynikiem z okresu poprzedniego,

- wynikami innych przedsiębiorstw, szczególnie konkurencyjnych,

- okresem rotacji zobowiązań z tytułu dostaw i usług.

Okres rotacji należności powinien wykazywać tendencję malejącą. W takiej sytuacji środki w nich zamrożone zostają upłynniane w coraz krótszym okresie. Należy również porównać czas oczekiwania na zapłatę należności z terminami płatności zobowiązań, szczególnie z tytułu dostaw i usług.

Kredyt kupiecki powinien mieć precyzyjnie określone warunki jego udzielenia. Należą do nich okres zapłaty oraz warunki dyskonta w cenie (opusty) (Golawska-Witkowska, Rzeczycka, Zalewski 2006, s. 159 i nast.)

Okres dokonywania płatności jest negocjowany przez strony transakcji kupna - sprzedaży. Zależy od wielu czynników, jak np.:

- branży, w której realizowana jest transakcja,

- kraju pochodzenia odbiorcy,

- wiarygodności kupującego i jego kondycji ekonomiczno-finansowej.

Obecnie okres zapłaty powinien być spójny z postanowieniami Ustawy o terminach zapłaty w transakcjach handlowych, która weszła w życie w dniu 28 kwietnia 2013 roku i zastąpiła poprzednio obowiązującą Ustawę z dnia 12 czerwca 2003 roku (Ustawa z dnia 8 marca 2013 roku). Zgodnie z przyjętymi postanowieniami termin zapłaty w transakcjach między przedsiębiorcami nie powinien przekraczać 
60 dni kalendarzowych, a między przedsiębiorstwami i podmiotami publicznymi - 30 dni. Może być on wydłużony w przypadku spełnienia określonych warunków o charakterze społeczno-gospodarczym. Konsekwencją przekroczenia terminu jest możliwość naliczenia przez wierzyciela odsetek ustawowych za opóźnienie w wysokości równej sumie stopy referencyjnej NBP i ośmiu punktów procentowych. Ustawa wprowadziła również ryczałtową kwotę w postaci rekompensaty za koszty odzyskiwania należności w wysokości stanowiącej równowartość w złotych kwoty 40 euro. W Polsce podejmowane są również inne działania ograniczające zatory płatnicze. Dotyczą one rozliczeń w podatku dochodowym oraz podatku od towarów i usług.

W I etapie zarządzania kredytem kupieckim określa się również wiarygodność nabywcy towarów i usług. Jedną z metod jest metoda „pięciu C”. Pozwala ona na dokonanie oceny klienta, biorąc pod uwagę takie jego cechy, jak charakter, możliwości płatnicze, kapitał, gwarancje oraz warunki gospodarcze (Michalski 2013, s. 179).

W I etapie przeprowadza się też ocenę zasadności zmian polityki kredytowej. Przedsiębiorstwa, pragnąc sprostać wymogom konkurencji, w wielu przypadkach muszą rozważyć możliwość wydłużenia terminu płatności. Muszą więc określić stopę zwrotu z kapitału zamrożonego w należnościach, których termin płatności został wydłużony. Innymi słowy przedsiębiorcy, inwestując w należności, zamrażają w nich kapitały i oczekują generowania zysków z tego rodzaju przedsięwzięcia.

Bardzo ważnym elementem zarządzania należnościami z tytułu dostaw i usług jest ich ubezpieczenie. Celem zawartych umów jest zabezpieczenie się przed niewypłacalnością odbiorców towarów czy usług. Odszkodowanie ubezpieczeniowe będzie się należało ubezpieczającym się, gdy odbiorcy trwale zaprzestaną regulowania swoich zobowiązań z tytułu dostaw i usług.

W II etapie firmy mogą skorzystać z faktoringu, czyli sprzedają nieprzeterminowane należności. Jest on szczególnie korzystny dla faktoranta, ponieważ powoduje:

- zamianę należności na płynne środki pieniężne,

- poprawę płynności finansowej wraz ze stabilizacją pieniężną przedsiębiorstwa,

- zmniejszenie ryzyka kredytowego prowadzonej działalności.

III etap obejmuje działania mające na celu ściąganie należności. Jest on aktywowany, gdy działania wcześniej rozpoczęte (etap I i II) stały się nieskuteczne. Na tym etapie firmy powinny ustalić, kto będzie prowadzić ściąganie należności: czy będą to działania samego przedsiębiorstwa, czy skorzysta z usług firm windykacyjnych. Muszą również określić, czy będą ściągać należności rygorystycznie, czy podejmą bardziej elastyczne działania. Gdy firmy same podejmują się windykowania należności, to ich działania polegają na:

- wysyłaniu upomnień o przeterminowanych należnościach,

- przeprowadzaniu rozmów telefonicznych z kierownictwem firm zalegających z płatnościami,

- wszczynaniu postępowania sądowego. 
Należy jednak stwierdzić, że przedstawione wyżej działania ograniczające negatywne skutki odroczonych płatności nie zawsze są podejmowane przez przedsiębiorstwa. Świadczą o tym wyniki badań prowadzonych przez BIG InfoMonitor (tabela 10).

Tabela 10. Proponowane i realizowane działania ograniczające ryzyko kredytowe z tytułu odroczonych płatności

\begin{tabular}{|c|c|c|}
\hline $\begin{array}{c}\text { Proponowane działania } \\
\text { ograniczające ryzyko } \\
\text { kredytowe }\end{array}$ & $\begin{array}{c}\text { Działania prewencyjne } \\
\text { przedsiębiorstw } \\
(\%)\end{array}$ & $\begin{array}{c}\text { Dziatania realizowane } \\
\text { w celu odzyskania } \\
\text { niezaptaconych należności } \\
(\%)\end{array}$ \\
\hline $\begin{array}{l}\text { - ocena własnej sytuacji } \\
\text { w zakresie należności }\end{array}$ & $\mathrm{Bd}$ & $\mathrm{Bd}$ \\
\hline - ocena wiarygodności klienta & 19 & - \\
\hline $\begin{array}{l}\text { - informacja o kliencie } \\
\text { z wywiadowni }\end{array}$ & - & - \\
\hline - stosowanie przedpłat & 14 & - \\
\hline - ubezpieczenie transakcji & 4 & - \\
\hline - faktoring & 1 & - \\
\hline - dzwonienie, negocjowanie & - & 24 \\
\hline - wezwanie do zapłaty & 24 & 28 \\
\hline - odsetki ustawowe & 2 & - \\
\hline - windykacja & 19 & 27 \\
\hline - sąd, komornik & - & 43 \\
\hline - wpis do rejestru dłużników & - & 3 \\
\hline - blokada dostaw & 11 & 3 \\
\hline - odmowa współpracy & - & 1 \\
\hline - nie wiem & 6 & - \\
\hline
\end{tabular}

Źródto: opracowanie własne na podstawie BIGInfoMonitor 2015.

Analizując działania przedsiębiorstw, należy stwierdzić, że aż 14\% badanych stosuje przedpłaty $\mathrm{w}$ realizowanych transakcjach. Potwierdza to brak zaufania do kontrahenta wynikający $\mathrm{z}$ asymetrii informacji. Jednocześnie należy stwierdzić, że nie są wystarczające działania w zakresie zarządzania odroczonymi płatnościami. Tylko 19\% badanych analizuje sytuację ekonomiczno-finansową klienta, $4 \%$ korzysta $\mathrm{z}$ ubezpieczenia transakcji, a tylko $1 \%$ wykorzystuje faktoring. Nieco lepiej wygląda sytuacja w zakresie ściągania należności. Przedsiębiorcy aktywnie prowadzą negocjacje. Wykorzystują również metody prawne, jednak tylko 3\% przedsiębiorstw korzysta z wpisu do rejestru dłużników i blokuje dostawy. 


\section{Podsumowanie}

Udzielanie kredytu kupieckiego jest wpisane w działalność każdego przedsiębiorstwa. Odroczone płatności sprzyjają wzrostowi sprzedaży, ale również mogą powodować perturbacje w ich funkcjonowaniu. Na podstawie przeprowadzonych rozważań stwierdzono, że problemy płynnościowe wywołane są przez czynniki zewnętrzne i wewnętrzne. Czynnikami je kształtującymi są więc polityka monetarna i fiskalna oraz koniunktura gospodarcza. Jednak na nie przedsiębiorstwo nie ma większego wpływu.

Ważne są więc działania samych przedsiębiorstw, głównie w zakresie zarządzania kredytem kupieckim. Gdyby działania dotyczące I i II etapu zarządzania należnościami z tytułu dostaw i usług były lepiej wykonywane, można przypuszczać, że III etap byłby realizowany w mniejszym zakresie. Udzielając kredytu kupieckiego, każde przedsiębiorstwo narażone jest na ryzyko kredytowe, a w konsekwencji - ryzyko płynności. Tworzące się zatory płatnicze, mimo stosowanych przez państwo instrumentów prawnych w postaci Ustawy o terminach dostaw, stanowią istotną przeszkodę w działalności firm. W związku z powyższym konieczne jest zarządzanie kredytem kupieckim i dalsze doskonalenie działań z nim związanych. Przedsiębiorstwa powinny więc włączyć do działań ograniczających negatywne skutki kredytu kupieckiego nowe metody sprawdzania kondycji ekonomiczno-finansowej kontrahenta oraz instrumenty finansowe ograniczające wspomniane ryzyko.

\section{Bibliografia}

Golawska-Witkowska G., Rzeczycka A., Zalewski H. (2006), Zarządzanie finansami przedsiębiorstwa, Oficyna Wyd. Branta, Bydgoszcz.

Jaworski J. (2010), Teoria i praktyka zarzązania finansami przedsiębiorstw, CeDeWu, Warszawa.

Kreczmańska-Gogol K. (2015), Płynność finansowa przedsiębiorstwa, Difin, Warszawa.

Mały Rocznik RP, GUS, Warszawa 2005-2015

Michalski G. (2013), Płynność finansowa w małych i średnich przedsiębiorstwach, Wydawnictwo Naukowe PWN, Warszawa.

Raport Barometr płatności na świecie (2014), Bisnote D\&B Polska.

Raport BIGInfoMonitor (2015), listopad.

Roczniki Statystyczne Rzeczypospolitej Polskiej (2010-2015), GUS, Warszawa.

Rocznik Statystyczny Rzeczypospolitej Polskiej, GUS, Warszawa 2005-2015.

Ustawa z dnia 8 marca 2013 r. o terminach zapłaty w transakcjach handlowych (Dz.U. z 2013 r., poz. 403 z późniejszymi zmianami).

Ustawa z dnia 2 lipca 2004 r. o swobodzie działalności gospodarczej (Dz.U. Nr 173, poz. 1807, art. 22.1 z późniejszymi zmianami).

www.rRaportBIG.pl 


\section{ZATORY PŁATNICZE A ODROCZONE PŁATNOŚCI}

\section{Streszczenie}

Udzielanie kredytu kupieckiego jest wpisane w działalność każdego przedsiębiorstwa. Odroczone płatności sprzyjają wzrostowi sprzedaży, ale również mogą powodować perturbacje w ich funkcjonowaniu. Wpływają na funkcjonowanie przedsiębiorstwa w warunkach ryzyka kredytowego, które przekształca się często w ryzyko płynności. W efekcie tworzą się zatory płatnicze. Celem artykułu jest przedstawienie zatorów płatniczych jako skutków odroczonych płatności sprzyjających tworzeniu się ryzyka kredytowego oraz ujemnych luk płynności. Stwierdzono, że kredyt kupiecki może dla wielu firm stanowić istotną przeszkodę w działalności gospodarczej. Podjęto się więc próby oszacowania przyczyn występowania oraz wskazania potencjalnych i realnych metod ograniczania jego skutków.

Na podstawie przeprowadzonych rozważań stwierdzono, że problemy płynnościowe wywołane są przez czynniki zewnętrzne i wewnętrzne. Ich przyczynami są więc polityka monetarna i fiskalna oraz koniunktura gospodarcza. Jednak na nie przedsiębiorstwo nie ma większego wpływu. Ważne są więc działania samych przedsiębiorstw, głównie w zakresie zarządzania kredytem kupieckim.

Tworzące się zatory płatnicze, mimo stosowanych przez państwo instrumentów prawnych w postaci Ustawy o terminach dostaw, stanowią istotną przeszkodę w działalności firm. W związku z powyższym konieczne jest zarządzanie kredytem kupieckim i dalsze doskonalenie działań z nim związanych. Przedsiębiorstwa powinny więc włączyć do działań ograniczających negatywne skutki kredytu kupieckiego nowe metody sprawdzania kondycji ekonomiczno-finansowej kontrahenta oraz instrumenty finansowe ograniczające wspomniane ryzyko.

Słowa kluczowe: należności, kupiecki, odroczone płatności, ryzyko kredytowe, ryzyko płynności, zatory płatnicze, kredyt

\section{PAYMENT DELAYS AND DEFERRED PAYMENTS}

\section{Summary}

The trade credit is included in the activities of each company. Deferred payments are conducive to the growth of sales, but can also cause disturbances in their functioning. They facilitate the operation of companies in terms of credit risk, which turns up frequently in liquidity risk. As a result, they create a congestion payments.

The aim of the article is to present the payments delays as the effects of the deferred payments, conducive to the formation of credit risk and negative liquidity gaps. It was found that the trade credit for many companies may constitute a significant obstacle in their economic activity. So there were undertaken attempts to assess the causes of the occurrence and to identify potential and real methods of limiting its effects.

Based on the investigations stated that liquidity problems are caused by external and internal factors. The factors shaping them they are the monetary and fiscal policies and the economic conditions. However, no company has influence on it. Important action has therefore the enterprise, mainly in the management of the trade credit.

The payment bottlenecks, which arise despite of the imposed by the State the legal instruments in the form of the Law on delivery dates, are important obstacle to the activities of companies. Therefore, it is necessary to manage trade credit and further improvement of related activities. Enterprises should therefore include to the measures of the limit of the negative effects of the credit, the new methods of checking the financial and economic situation of the customers, and financial instruments, limiting these risks.

Keywords: debt, merchant, deferred payments, credit risk, liquidity risk, payment backlogs, payment delays, credit 